\title{
8. FROM THALES TO BERIO: WATER AS A COMMON THEME OF PHILOSOPHY, PHYSICS, AND MUSIC
}

\section{Rossella Marisi ${ }^{74}$}

\begin{abstract}
Listening to a music piece may trigger memories, give origin to reflections about the physical state of matter, and retrace the development of ancient philosophical thought. This article proposes an interdisciplinary path of active learning - encompassing music education, philosophy, biology, physics, and psychology - which can be realized, choosing an appropriate approach, in both primary and secondary schools.
\end{abstract}

Key words: Berio, Debussy, interdisciplinary project, Liszt, Ravel, water

\section{Introduction}

Teachers can stress the unity of knowledge proposing interdisciplinary projects centered on a common theme, and guiding their pupils at focusing on the links among different points of view. Water may be an interesting theme to reflect on. For many centuries natural philosophers focused on the problem of the nature of matter and its transformations. The Greek philosopher Thales (c. 624-548 B.C.), centered his research on water, positing that it could be the basic element which gave rise to everything in the world ${ }^{75}$. The first observation might have been that water can readily be observed in the three physical states of liquid water, ice, and steam. Moreover, it is quite usual that coasts and river banks show a constant increase in size, and this may have suggested the belief that water had the capacity to thicken into earth. This theory has been proven wrong only in the eighteenth century, following experiments of Antoine Lavoiser (1743-1794).

Furthermore, the high concentration of nutrients in wetland water, which feeds different species of plants and animals, gave rise to the theory of spontaneous generation. This misconception was disproved only in the nineteenth century, as a result of the work of Louis Pasteur (1822-1895). Indeed, it is quite unsurprising that water has been considered of major importance to all living things; we know now that in some organisms, up to $90 \%$ of their body weight comes from water, and in the human adult body up to $60 \%$ is water. After Thales, also the Sicilian poet and philosopher Empedocles (495-430 B.C.) centered his research on the basic elements (water, earth, air, and fire), which he called roots, defining them as both, material substances and spiritual essences ${ }^{76}$.

\footnotetext{
${ }^{74}$ Doctoral Candidate, Italy, "George Enescu” University of Arts from Iaşi of Romania, email:rossellamarisi@hotmail.it

${ }^{75}$ Marvin Perry, Myrna Chase, James R. Jacob, Margaret C. Jacob, Jonathan W. Daly, Theodore H. Von Laue (2013), Western Civilization: Ideas, Politics, and Society, Cengage Learning, Boston, 73

${ }^{76}$ John E. Sisko (2014), Anaxagoras and Empedocles in the Shadow of Elea. In: James Warren and Frisbee Sheffield (eds.) (2014), The Routledge Companion to Ancient Philosophy, Routledge, New York, 49-63
} 


\section{Discussions}

Also modern psychology focuses on these elements, considering them as archetypes, that is universal structures in the collective unconscious ${ }^{77}$. Besides scientists and natural philosophers, also many musicians pointed their attention on waterbodies, such as seas, lakes, sources, and on precipitations as snow and rain. Among these composers are Antonio Vivaldi (1678-1741), whose Concerto in E flat major RV 253 for violin, string and basso continuo, is called "The sea storm", Ernest Bloch (1880-1959), who wrote Poems of the Sea, Franz Liszt (1811-1886) who composed $A u$ lac de Wallenstadt and Au bord d'une source, and Claude Debussy (1862-1918) who wrote Jardins sous la pluie and Des pas sur la neige. However, in this article I limit the scope of my research to the examination of some pieces whose titles refer exactly to the general term "water": Les jeux d'eau à la villa d'Este, by Liszt, Reflets dans l'eau, by Debussy, Jeux d'eau by Maurice Ravel (1875-1937), and Wasserklavier by Luciano Berio (1925-2003).

In these pieces the composers hinted to specific characteristics of water fluidity, undulation, wetness, and reflectivity - and depicted them using musical means. Fluidity may be defined as the state of a substance whose molecules move freely past one another. This characteristic can be depicted by means of ceaseless motion: such an effect can be obtained using specific intervals, rhythmic figurations, and meter changes. In the selected pieces there is a frequent use of particular intervals, such as seconds and fourths, which are quite unstable tone combinations. The tension deriving from this instability demands an onward motion to more stable combinations such as thirds and fifths ${ }^{78}$.

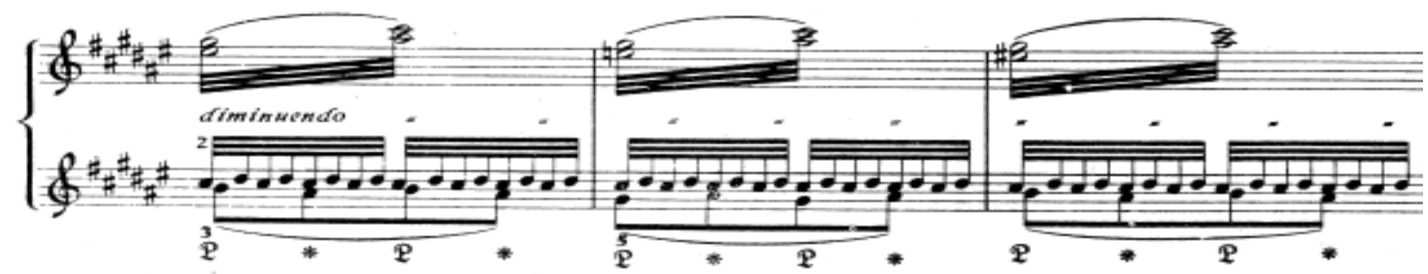

Ex. 1, Liszt, Les jeux d'eau à la Villa d'Este, measures 27-29

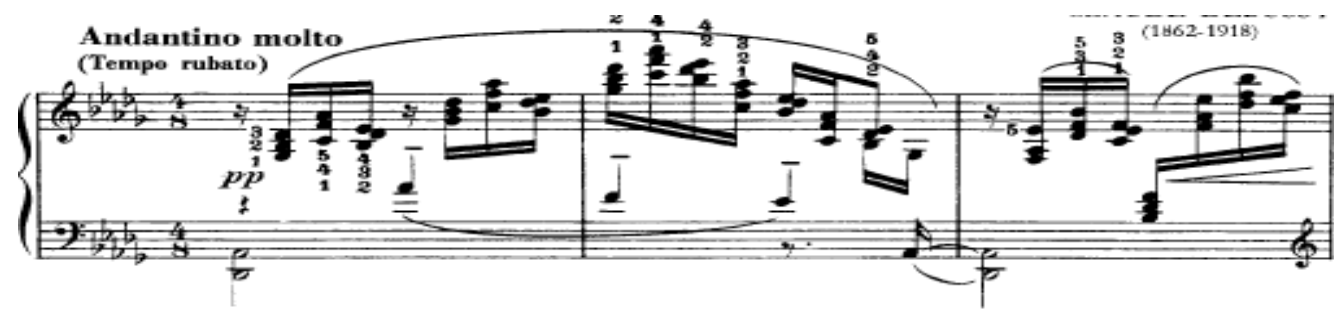

Ex. 2, Debussy, Reflets dans l'eau, measures 1-

\footnotetext{
${ }^{77}$ Carl Gustav Jung (1954). Archetypes of the Collective Unconscious. In Herbert Read, Michael Fordham \& Gerhard Adler (eds.) (1959), The Archetypes and the Collective Unconscious, 2nd ed., Vol. 9(I), Princeton University Press, Princeton, 3-41

${ }^{78}$ Roger Kamien (2008), Music: An Appreciation, sixth brief edition, Boston: McGraw-Hill Higher Education, Boston, 41
} 


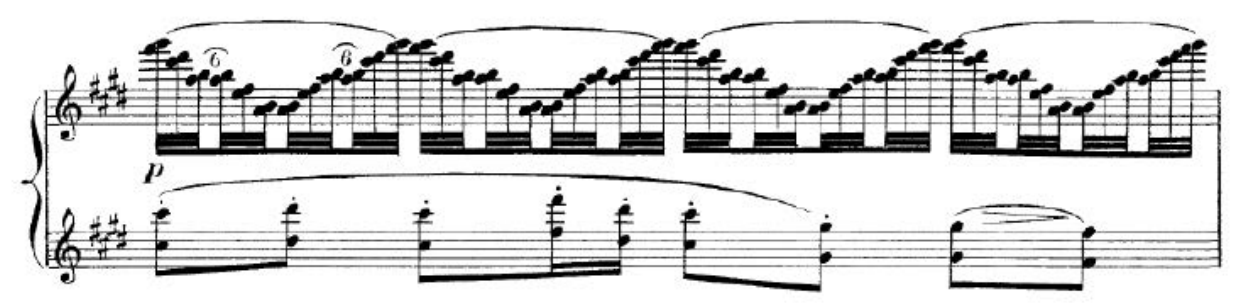

Ex. 3, Ravel, Jeux d'eau, measure 78

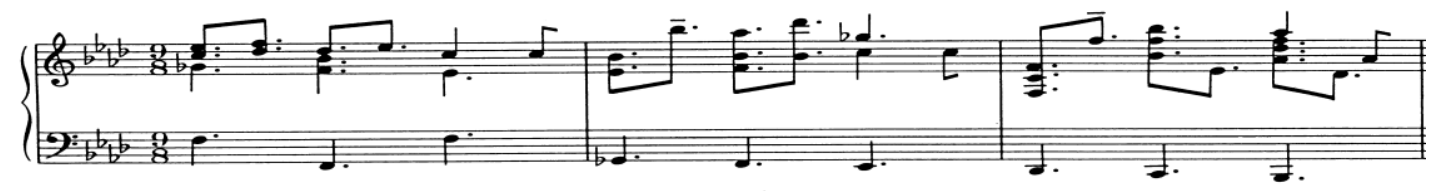

Ex. 4, Berio, Wasserklavier, measures 6-8

Fluidity is enhanced also by fast figurations, which may be written out in short value notes, such as sixteenth-note, thirty-second-note, or sixty-fourth-note values, as in the following examples,

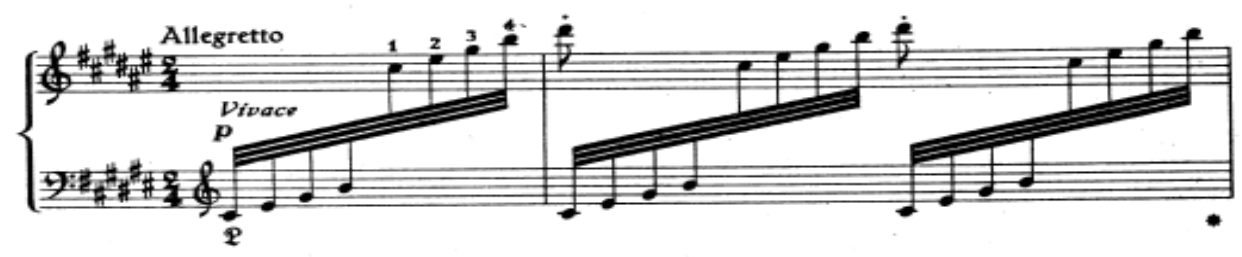

Ex. 5, Liszt, Les jeux d'eau à la Villa d'Este, measures 1-2

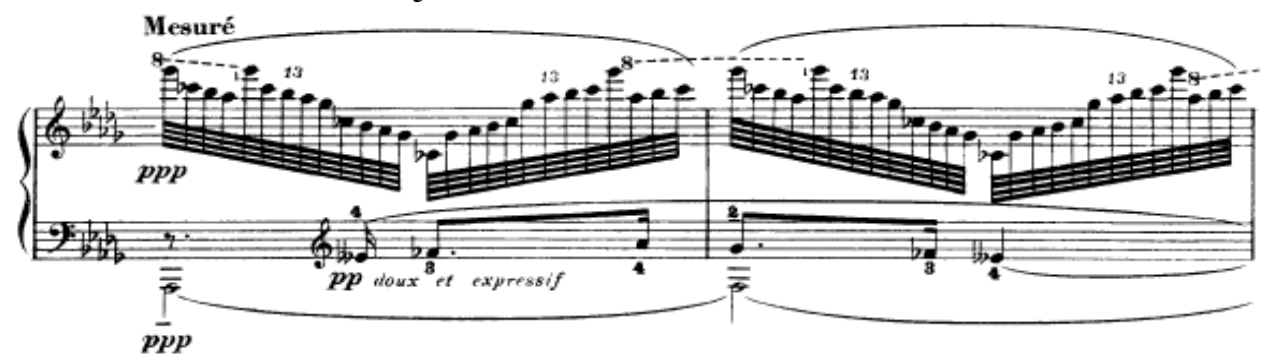

Ex. 6, Debussy, Reflets dans l'eau, measures 24-25

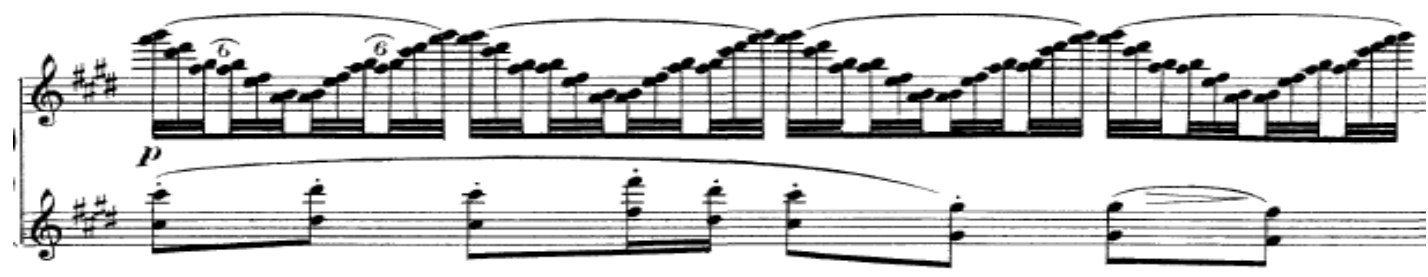

Ex. 7, Ravel, Jeux d'eau, measure 78

or prescribed by specific directions included in the score: in Wasserklavier a footnote recommends to perform grace notes and arpeggios very fast. A third way in which fluidity can be alluded to is by means of irregular groups and meter changes, as we can see in the following examples 


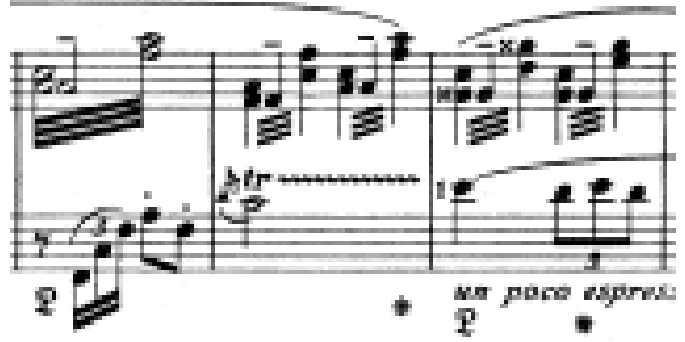

Ex. 8, Liszt, Jeux d'eau à la Villa d'Este, measures 47-49

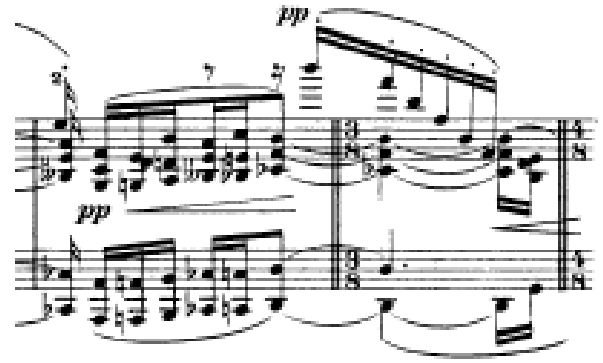

Ex. 9, Debussy, Reflets dans l'eau, measures 10-11

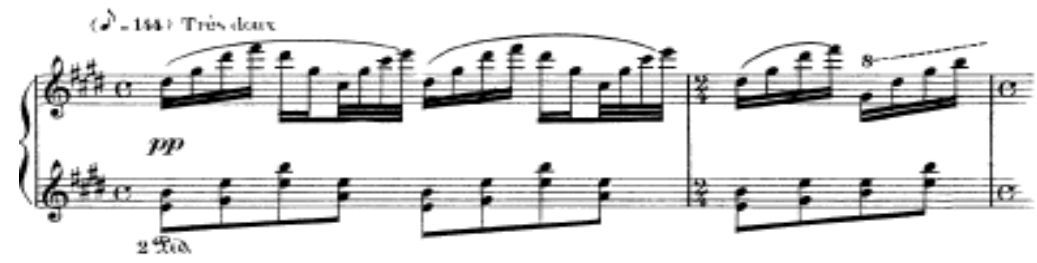

Ex. 10, Ravel, Jeux d'eau, measures 1-2

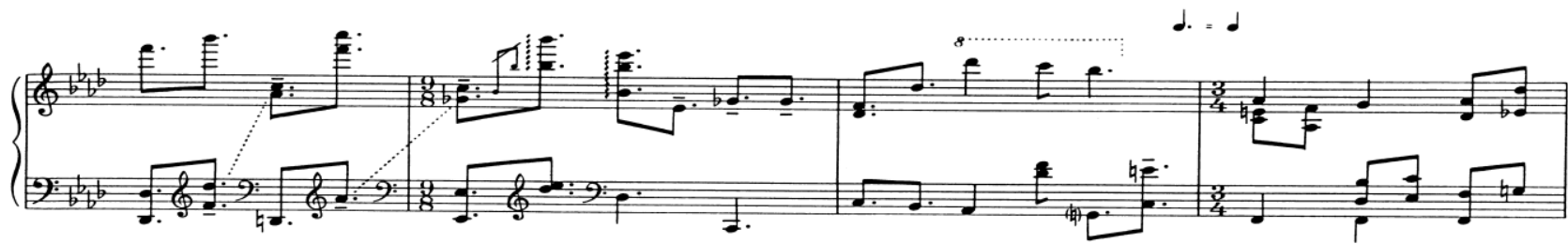

Ex. 11, Berio, Wasserklavier, measures 14-17

Undulation is depicted by means of melodies based on ascending and descending scales and arpeggios, which are frequently repeated with some minor changes, conferring to the passage a substantial staticity.

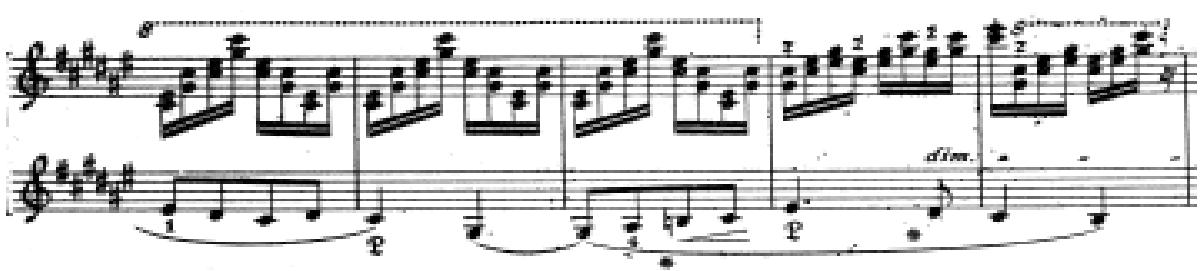

Ex. 12, Liszt, Les jeux d'eau à la Villa d'Este, measures 58-62
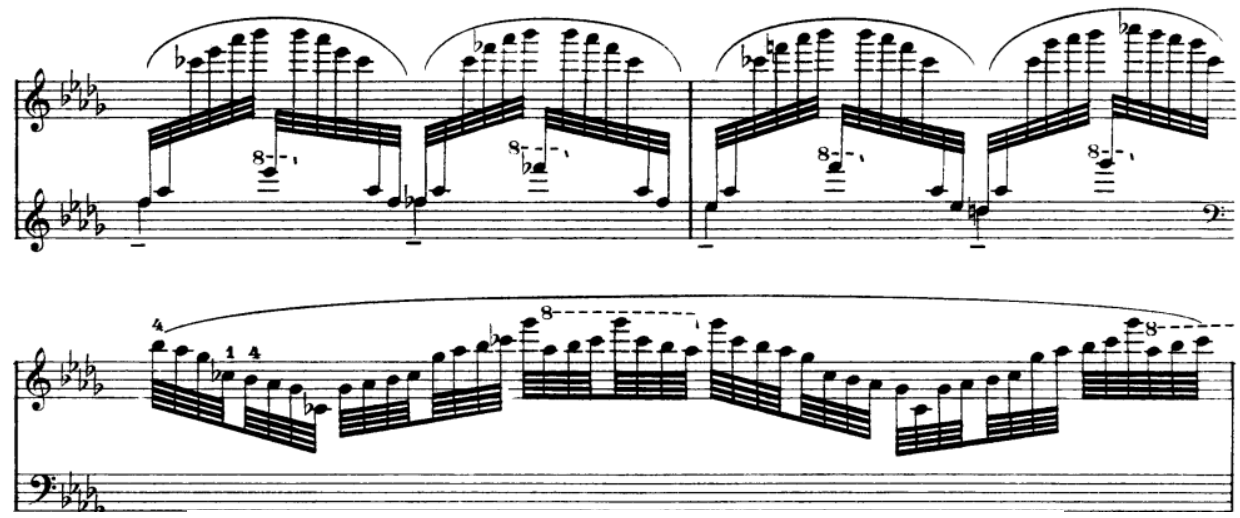

Ex. 13, Debussy, Reflets dans l'eau, measures 22-23

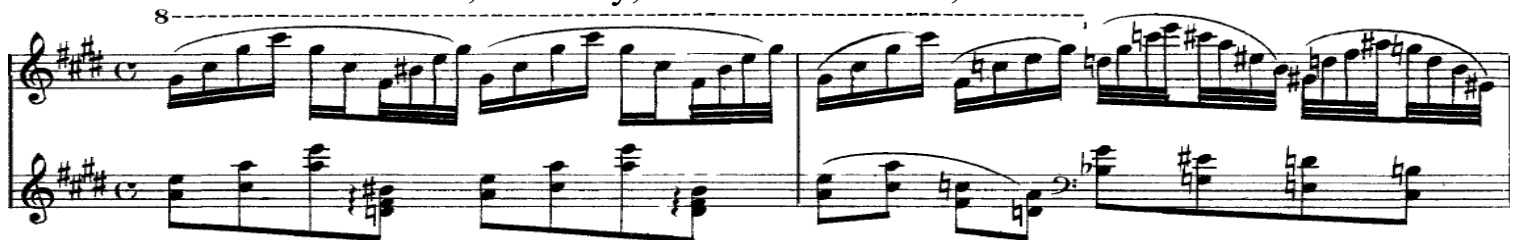

Ex. 14, Ravel, Jeux d'eau, measures 3-4 


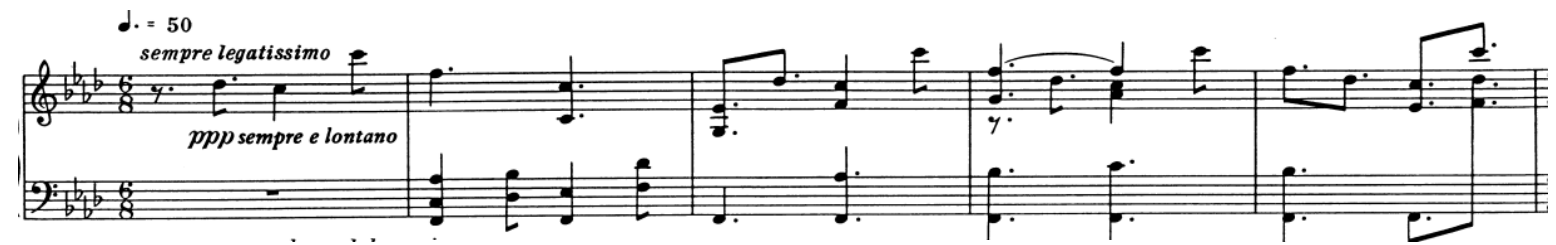

Ex. 15, Berio, Wasserklavier, measures 1-5

Undulation is also depicted by means of tremolos, as shown in the following examples

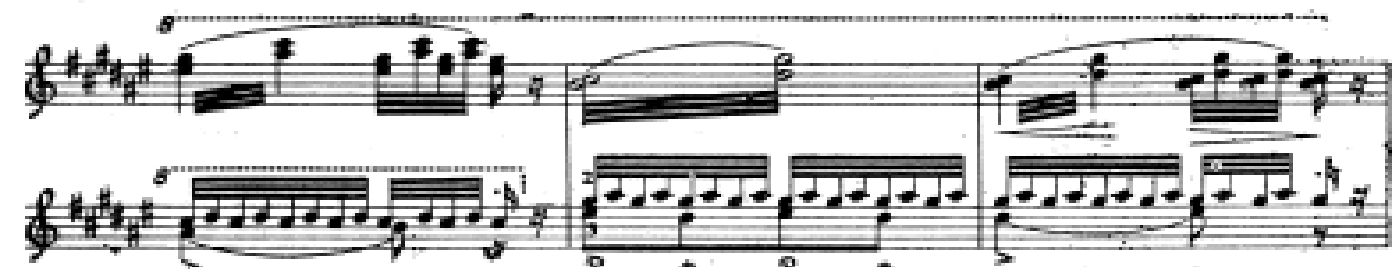

Ex. 16, Liszt, Les jeux d'eau à la Villa d'Este, measures 24-26
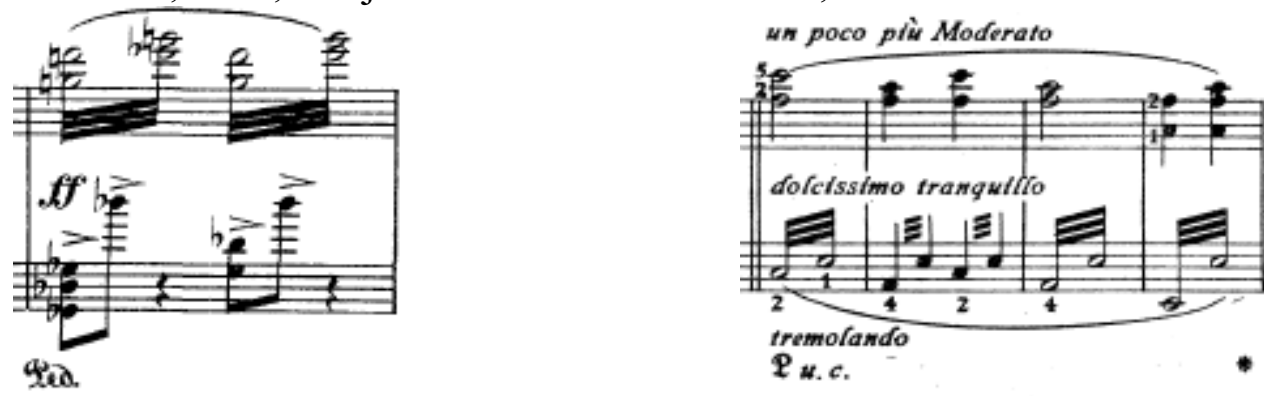

Ex. 17, Ravel, Jeux d'eau, measure 26 Ex. 18, Liszt, Les jeux d'eau à la Villa d'Este, measures 41-44

Wetness is alluded to by prescribing the contemporary use of both, the sustaining and the damping pedal, as shown in the following examples
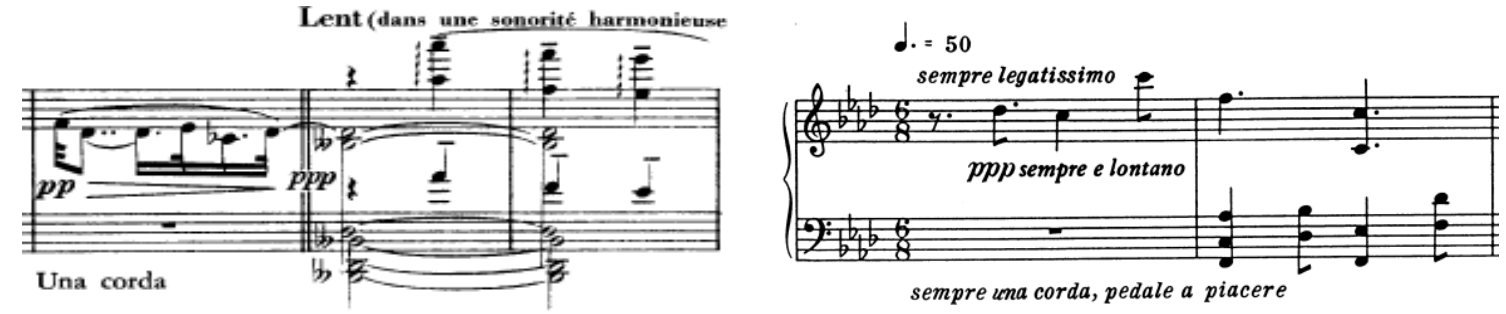

Ex. 19, Debussy, Reflets dans l'eau, measures $80-82$

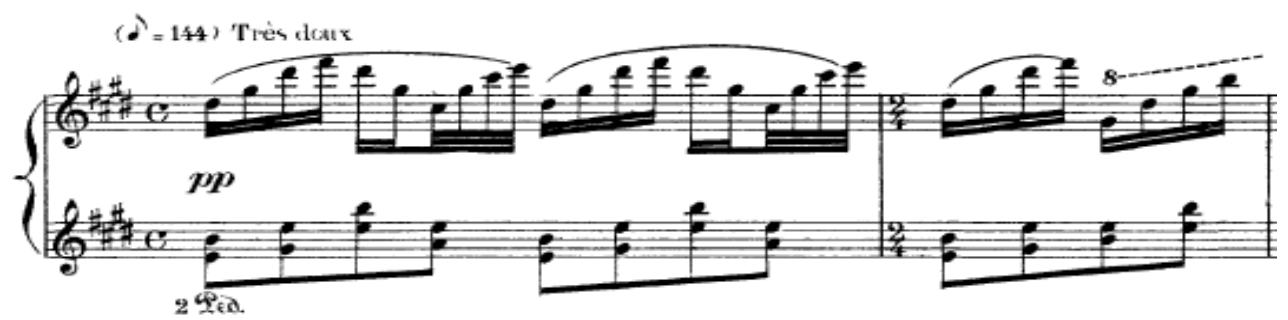

Ex. 20, Ravel, Jeux d'eau, measures 1-2

Reflectivity is depicted by means of both, horizontal and vertical symmetry, such as in the following examples 


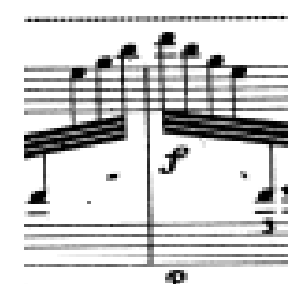

Ex. 22, Liszt, Les jeux d'eau à la Villa d'Este, measures 10-11

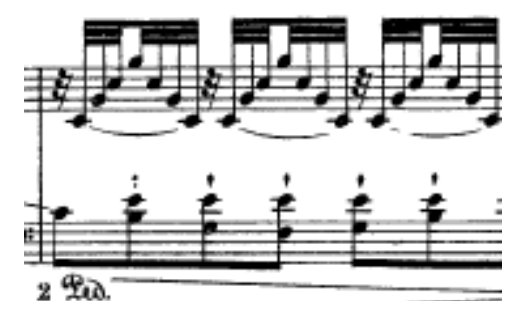

Ex. 24, Ravel, Jeux d'eau, measure 16

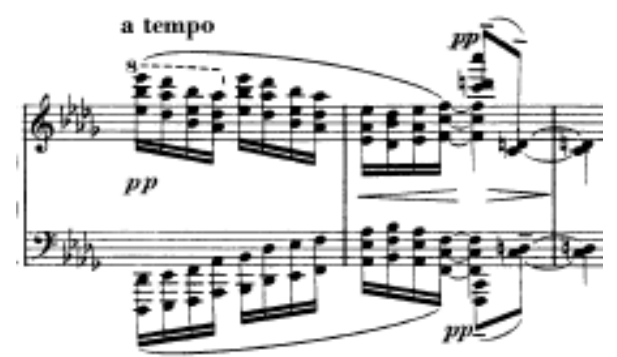

Ex. 23, Debussy, Reflets dans l'eau, measures 16-18

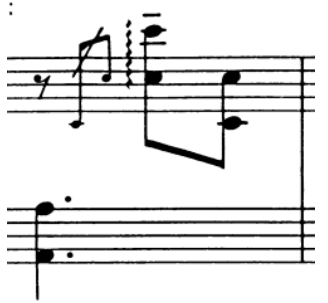

Ex. 25, Berio, Wasserklavier, measure 13

Furthermore, some peculiarities of Ravel's and Berio's pieces may call to mind the theory proposed by the French researcher Jacques Benveniste (19352004), according to whom water molecules can communicate with each other, exchanging information even without being in physical contact ${ }^{79}$. In effect Ravel's Jeux d'eau show already in its title that it was inspired by Liszt's piece Les jeux d'eau à la Villa d'Este ${ }^{80}$, and some peculiarities of Berio's piece seem to hint at well-known works by other composers ${ }^{81}$. As we can see in the following examples, Wasserklavier shares the F minor key, as well as the first and last chord performed by the left hand with the Impromptu op. $142 \mathrm{n} 1$ by Franz Schubert (1797-1828), Moreover, the right hand motive which appears in the first measures of Wasserklavier recalls the one at the beginning of an Intermezzo by Johannes Brahms (1833-1897).
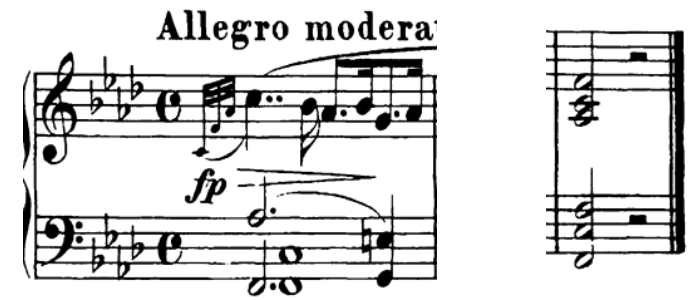

Ex. 26, Schubert, Impromptu op. 142 n 1, first and last measure
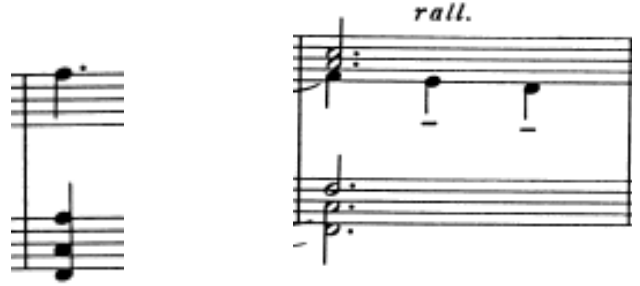

Ex. 27, Berio, Wasserklavier, first and last measure

\footnotetext{
${ }^{79}$ Yolène Thomas (2007), The history of the Memory of Water, in "Homeopathy", 96(3), July 2007, 151-157.

${ }^{80}$ Arbie Orenstein (1991), Ravel: man and musician, Courier Dover Publications, New York, 154

${ }^{81}$ Jinyoung Kim (2014), A study and performance guide to Luciano Berio's Encores pour piano, dissertation, Ohio State University, 14
} 


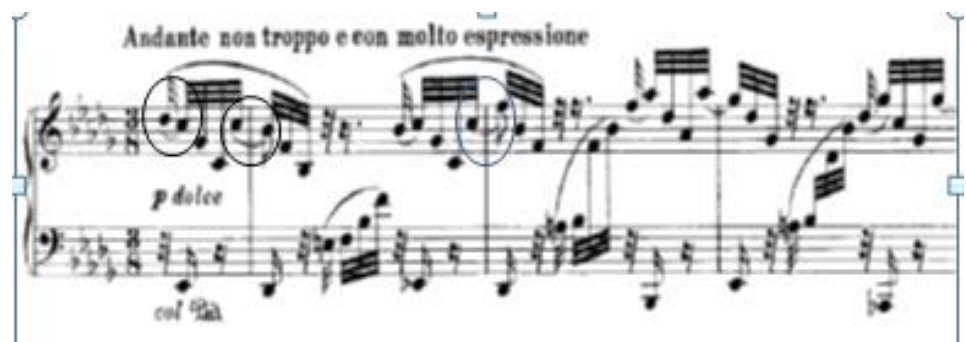

Ex. 28, Brahms, Intermezzo op. 117 n 2, measures 1-4

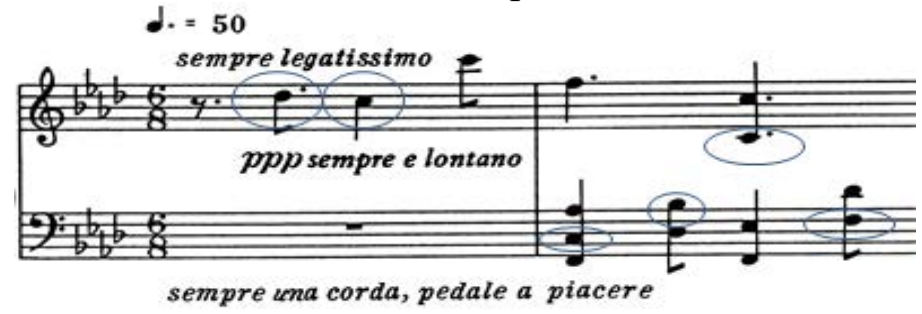

Ex. 29, Berio, Wasserklavier, measures 1-2

\section{Conclusions}

According to a different view, the connections between these pieces may have been triggered by the composer's memory, and thus be related to psychological, rather than physical processes. Concluding, guiding pupils in listening to selected music pieces and analyzing the latter at different levels can be a very interesting activity to be included in interdisciplinary projects encompassing philosophy, biology, physics, and psychology. In turn, highlighting the connections between different disciplines can offer to children, adolescents, and adults, a compelling way of understanding the unity of knowledge.

\section{References}

1. Jung, C. G. (1954). Archetypes of the Collective Unconscious. In: Read, H., Fordham, M. \& Adler, G. (eds.) (1959), The Archetypes and the Collective Unconscious, 2nd ed., Vol. 9(I), (pp. 3-41). Princeton: Princeton University Press

2. Kamien, R. (2008). Music: An Appreciation, sixth brief edition, Boston: McGrawHill Higher Education

3. Kim, J. (2014). A Study and Performance Guide to Luciano Berio's Encores pour Piano, [Dissertation]. Ohio State University

4. Orenstein, A. (1991). Ravel: Man and Musician, New York: Courier Dover Publications

5. Marvin, P., Myrna, C., Jacob, J., Jacob, M. C., Daly, J. W., Von Laue T. H. (2013). Western Civilization: Ideas, Politics, and Society, Boston: Cengage Learning

6. Read H., Fordham M. \& Adler G. (eds.) (1959). The Archetypes and the Collective Unconscious, 2nd ed., Vol. 9(I), Princeton: Princeton University Press

7. Sisko, J. E. (2014). Anaxagoras and Empedocles in the Shadow of Elea. In: James Warren and Frisbee Sheffield (eds.), The Routledge Companion to Ancient Philosophy, (pp. 49-63) New York: Routledge

8.Yolène, T. (2007). The history of the Memory of Water. Homeopathy, 96(3), 151157

9. Warren J. \& Sheffield F. (eds.) (2014). The Routledge Companion to Ancient Philosophy. New York: Routledge 